\title{
PENERAPAN TEORI BELAJAR SOSIAL ALBERT BANDURA DALAM PROSES BELAJAR MENGAJAR DI SEKOLAH
}

\section{Herly Janet Lesilolo}

\author{
Dosen Pastoral Konseling \\ Fakultas Ilmu Sosial Keagamaan \\ Institut Agama Kristen Negeri Ambon \\ Email: bunda_noa@yahoo.com
}

\begin{abstract}
In order for learning to be fun so the lesson should has an activity to obtain information and new competencies. Learning activities that choice should have to be bridged between the knowledge that has been owned by the learners previously with new knowledge that will be built by the learners. Proceeding to bridge namely:allowing learners to work on diverse activities in order to develop the skills and understanding with an emphasis learners learn by doing. Social learning form Albert Bandura is stressed on the importance of learners cultivate their own knowledge or information that derived from observations of the model around the environment.Learners arrange and organize all of the information in the specific codes. The process of preparation of each code to be repeated, so that learners anytime properly can provide real-time feedback. Behavior of learners is the result of the ability of learners to interpret of knowledge or information, a model to imitate, then cognitively process and determine the appropriate action desired destination. Learners are encouraged to think critically and creatively. Critical to analyze problems and deliver alternative solutions to problems.
\end{abstract}

Keywords : social learning, teaching and learning process in schools

\begin{abstract}
Abstrak
Agar belajar menjadi menyenangkan maka belajar seharusnya memiliki aktivitas untuk memperoleh informasi dan kompetensi baru. Aktivitas belajar yang dipilih harus menjembatani antara pengetahuan yang telah dimiliki peserta didik sebelumnya dengan pengetahuan baru yang akan dibangun peserta didik. Tindakan untuk menjembatani yaitu, memungkinkan peserta didik untuk mengerjakan kegiatan yang beragam dalam rangka mengembangkan keterampilan dan pemahamannya, dengan penekanan peserta didik belajar sambil bekerja.Bentuk belajar sosial Albert Bandura adalah menekankan tentang pentingnya peserta didik mengolah sendiri pengetahuan atau informasi yang diperoleh dari pengamatan model di sekitar lingkungan. Peserta didik mengatur dan menyusun semua informasi dalam kode-kode tertentu. Proses penyusunan setiap kode dilakukan berulang-ulang, sehingga peserta didik kapan saja dengan tepat dapat memberi tanggapan aktual. Perilaku belajar peserta didik adalah hasil dari kemampuan peserta didik memaknai suatu pengetahuan atau informasi, memaknai suatu model yang ditiru, kemudian mengolah secara kognitif dan menentukan tindakan sesuai tujuan yang dikehendaki. Peserta didik didorong agar berpikir kritis dan kreatif. Kritis untuk menganalisis masalah; dan kreatif untuk melahirkan alternatif pemecahan masalah.
\end{abstract}

Kata kunci : belajar sosial, proses belajar mengajar di sekolah 


\section{A. PENDAHULUAN}

Dalam situasi masyarakat yang selalu berubah-ubah, idealnya pendidikan tidak hanya berorientasi pada masa lalu dan masa kini, tetapi sudah seharusnya merupakan proses yang mengantisipasi dan membicarakan masa depan. Pendidikan hendaknya melihat jauh ke depan dan memikirkan apa yang akan dihadapi peserta didik di masa yang akan datang. Pendidikan yang baik adalah pendidikan yang tidak hanya mempersiapkan para siswanya untuk sesuatu profesi atau jabatan, tetapi pendidikan yang memberi pengalaman bagi peserta didik menyelesaikan masalahmasalah yang dihadapi dalam kehidupan sehari-hari.

Dalam proses belajar mengajar semestinya peserta didik tidak dijadikan layaknya penonton yang hanya duduk manis dan siap mendengarkan tentang ilmu pengetahuan dan informasi dari sang guru. Namun lebih dari itu seorang guru dituntut untuk mampu menciptakan suasana yang memungkinkan peserta didik aktif menemukan, memproses dan mengkontruksi ilmu pengetahuan dan keterampilan baru.

Proses belajar mengajar yang memungkinkan peserta didik aktif menemukan, memproses dan mengkontruksi ilmu pengetahuan dan keterampilan baru cenderung mempertemukan ilmu pengetahuan secara langsung melalui pengalaman. Peserta didik secara mandiri dapat melakukan kontak dengan segala realita dalam lingkungan hidupnya, ataupun pengetahuan yang diperoleh melalui catatan-catatan, buku-buku, kepustakaan. Peserta didik dapat terlibat dalam berbagai kegiatan yang mengembangkan pemahaman dan kemampuan mereka dengan penekanan pada belajar melalui berbuat. Guru menggunakan berbagai alat bantu dan berbagai cara dalam membangkitkan semangat, termasuk menggunakan lingkungan sebagai sumber belajar untuk menjadikan pembelajaran menarik, menyenangkan, dan cocok bagi siswa.Guru mengatur kelas dengan memajang buku-buku dan bahan belajar yang lebih menarik dan menyediakan 'pojok baca'. Guru menerapkan cara mengajar yang lebih kooperatif dan interaktif, termasuk cara belajar kelompokdanguru mendorong siswa untuk menemukan caranya sendiri dalam pemecahan suatu masalah, untuk mengungkapkan gagasannya, dan melibatkan siswa dalam menciptakan lingkungan sekolahnya.

Masalah utama dalam proses belajar mengajar di sekolah antara lain, masih rendahnya daya serap peserta didik. Hal ini tampak dari rerata hasil belajar peserta 
didik yang senantiasa masih sangat memprihatinkan. Prestasi ini tentunya merupakan kondisi hasil proses belajar mengajar yang masih bersifat konvensional dan tidak menyentuh ranah dimensi peserta didik yang senantiasa masih sangat memprihatinkan. Dalam arti yang lebih substansial, bahwa proses belajar mengajar hingga dewasa ini masih memberikan dominasi guru dan tidak memberikan akses bagi anak didik berkembang secara mandiri melalui penemuan dan proses berpikirnya.

Kenyataan di lapangan peserta didik menghafal konsep dan kurang mampu menggunakan konsep tersebut jika menemui masalah dalam kehidupan nyata yang berhubungan dengan konsep yang dimiliki. Lebih jauh lagi bahkan siswa kurang mampu menentukan masalah dan merumuskannya. Berbicara mengenai proses pembelajaran dan pengajaran yang sering membuat kita kecewa, apalagi dikaitkan dengan pemahaman siswa terhadap materi ajar. Sebagian besar siswa kurang mampu menghubungkan antara apa yang mereka pelajari dengan bagaimana pengetahuan tersebut akan dimanfaatkan/diaplikasikan pada situasi.

Berlakunya KurikulumBerbasis Kompetensi yang dituangkan melalui Kurikulum Tingkat Satuan Pendidikan (KTSP) menuntut perubahan paradigma dalam pendidikan pengajaran, khususnya pada jenis pendidikan formal (sekolah). Perubahan tersebut harus pula diikuti oleh guru yang bertanggung jawab atas penyelengaraan pembelajaran di sekolah (di dalam kelas ataupun di luar kelas). Berdasarkan hal tersebut, maka sangatlah urgen bagi para pendidik khususnya guru memahami karakteristik materi, peserta didik, metodologi pembelajaran dalam proses pembelajaran terutama berkaitan dengan pemilihan terhadap model-model pembelajaran modern.

Salah satu perubahan paradigma pembelajaran tersebut adalah orientasi pembelajaran yang semua berpusat pada guru (teacher centered) beralih berpusat pada murid (student centered); metodologi yang semula lebih didominasi ekspositori berganti ke partisipatori; dan pendekatan yang semula lebih banya bersifat tekstual berubah menjadi kontekstual. Semua perubahan tersebut dimaksudkan untuk memperbaiki mutu pendidikan, baik dari segi proses maupun hasil pendidikan.

Student centered mengandung pengertian pembelajaran menerapkan strategi pedagogi mengorientasikan peserta didik kepada situasi yang bermakna, kontekstual, dunia nyata dan menyediakan sumber belajar, bimbingan, petunjuk bagi pembelajar 
ketika mereka mengembangkan pengetahuan tentang materi pelajaran yang dipelajarinya sekaligus keterampilan memecahkan masalah. Paradigma yang menempatkan guru sebagai pusat pembelajaran (teaching) dan siswa sebagai objek, seharusnya diubah dengan menempatkan siswa sebagai subjek yang belajar secara aktif membangun pemahamannya (learning) dengan jalan merangkai pengalaman yang telah dimiliki dengan pengalaman baru yang dijumpai.

Situasi utama yang menjadi keaktifan student centereddi dalam kelas adalah munculnya rasa ingin tahu, ketertarikan dan minat siswa terhadap hal yang sedang dipelajari. Untuk itu, melalui berbagi teknik dan metode, guru harus berusaha sebisa mungkin untuk menciptakan suasana sedemikian rupa guna memicu rasa kepenasaran siswa aktif bertanya, mempertanyakan mengemukakan gagasan.

Guru tahu bahwa keaktifan peserta didik dalam proses belajar mengajar merupakan faktor penting, kegiatan aktif ini seharusnya tidaklahhanya berupa keterlibatan secara fisik belaka, tetapi hal yang lebih utama adalah keterlibatan mental atau intelektual, khususnya keterlibatan intelektual-emosional. Keterlibatan intelektual memberi peluang terjadinya asimilasi atau akomodasi kognitif terhadap pengetahuan baru, serta terbentuknya meta-kognisi kesadaran dan kemampuan untuk mengendalikan proses kognitifnya itu

Sudut pandang bahwa belajar mengajar seharusnya meliputi keaktifan berpikir tentang apa yang dipelajari. Kemudian bagaimana menerapkan apa yang telah dipelajari dalam situasi nyata sebagai akomodasi kognitif terhadap pengetahuan baru, telah menjadi kajian dalam teori belajar sosial Albert Bandura. Menurut Bandura, suatu perilaku belajar adalah hasil dari kemampuan individu memaknai suatu pengetahuan atau informasi, memaknai suatu model yang ditiru, kemudian mengolah secara kognitif dan menentukan tindakan sesuai tujuan yang dikehendaki. Dalam belajar setiap individu dapat menyadari bahwa, perilaku yang dilakukan memiliki tujuan dan konsekuensi.

Bentuk belajar sosial Albert Bandura adalah individu mengolah sendiri pengetahuan atau informasi yang diperoleh dari pengamatan model di sekitar lingkungan. Individu mengatur dan menyusun semua informasi dalam kode-kode tertentu. Proses penyusunan setiap kode dilakukan berulang-ulang, sehingga individu kapan saja dengan tepat dapat memberi tanggapan aktual. Proses belajar seperti ini adalah sangat efektif untuk meningkatkan pertumbuhan dan perkembangan individu, 
karena belajar adalah keseluruhan aktivitas manusia yang mencakup segala proses yang saling mempengaruhi antara organisme yang hidup dalam lingkungan sosial dan fisik.

Proses belajar mengajar dengan menerapkan cara belajar sosial, bukan merupakan pendekatan proses belajar mengajar yang baru, melainkan sudah dikenal dan populer, hanya saja sering terlupakan. Adapun yang dimaksud dengan menerapkan cara belajar sosialdalam prosesbelajar mengajar adalah belajar dengan yang memanfaatkan lingkungan sosial sebagai sasaran belajar, sumber belajar, dan sarana belajar. Proses belajar mengajar tidak terbatas pada empat dinding kelas. Guru dan siswa terlibat dalam berbagai kegiatan belajar mengajar dengan mengembangkan pemahaman pada belajar melalui berbuat, bukan belajar melalui membaca belaka.

\section{B. TEORI BELAJAR SOSIAL ALBERT BANDURA}

Teori pembelajaran sosial merupakan perluasan dari teori belajar perilaku yang tradisional (behavioristik). Teori pembelajaran sosial ini dikembangkan oleh Albert Bandura (1986). Teori ini menerima sebagian besar dari prinsip-prinsip teoriteori belajar perilaku, tetapi memberi lebih banyak penekanan pada efek-efek dari isyarat-isyarat pada perilaku, dan pada proses-proses mental internal.

Salah satu asumsi paling awal mendasari teori pembelajaran sosial Bandura adalah manusia cukup fleksibel dan sanggup mempelajari bagaimana kecakapan bersikap maupun berperilaku. Titik pembelajaran dari semua ini adalah pengalamanpenglaman tak terduga (vicarious experiences). Meskipun manusia dapat dan sudah banyak belajar dari pengalaman langsung, namun lebih banyak yang mereka pelajari dari aktivitas mengamati perilaku orang lain. ${ }^{1}$

Asumsi awal memberi isi sudut pandang teoritis Bandura dalam teori pembelajaran sosial yaitu: (1) Pembelajaran pada hakikatnya berlangsung melalui proses peniruan (imitation) atau pemodelan (modeling). (2) Dalam imitation atau modeling individu dipahami sebagai pihak yang memainkan peran aktif dalam menentukan perilaku mana yang hendak ia tiru dan juga frekuensi serta intensitas peniruan yang hendak ia jalankan. (3) Imitation atau modeling adalah jenis pembelajaran perilaku tertentu yang dilakukan tanpa harus melalui pengalaman langsung. (4) Dalam Imitation atau modeling terjadi penguatan tidak langsung pada perilaku tertentu yang sama efektifnya dengan penguatan langsung untuk 
memfasilitasi dan menghasilkan peniruan. Individu dalam penguatan tidak langsung perlu menyumbangkan komponen kognitif tertentu (seperti kemampuan mengingat dan mengulang) pada pelaksanaan proses peniruan. (5) Mediasi internal sangat penting dalam pembelajaran, karena saat terjadi adanya masukan indrawi yang menjadi dasar pembelajaran dan perilaku dihasilkan, terdapat operasi internal yang mempengaruhi hasil akhirnya. ${ }^{2}$

Bandura yakin bahwa tindakan mengamati memberikan ruang bagi manusia untuk belajar tanpa berbuat apapun. Manusia belajar dengan mengamati perilaku orang lain. Vicarious learning adalah pembelajaran dengan mengobservasi orang lain. Fakta ini menantang ide behavioris bahwa faktor-faktor kognitif tidak dibutuhkan dalam penjelasan tentang pembelajaran. Bila orang dapat belajar dengan mengamati, maka mereka pasti memfokuskan perhatiannya, mengkonstruksikan gambaran, mengingat, menganalisis, dan membuat keputusan-keputusan yang mempengaruhi pelajaran. Bandura percaya penguatan bukan esensi pembelajaran. Meski penguatan memfasilitasi pembelajaran, namun bukan syarat utama. Pembelajaran manusia yang utama adalah mengamati model-model, dan pengamatan inilah yang ters menerus diperkuat.

Fungsi penguatan dalam proses modeling, yaitu sebagai fungsi informasi dan fungsi motivasi. Penguat memiliki kualitas informatif maksudnya, tindakan penguatan dan proses penguatan itu sendiri bisa memberitahukan pada manusia perilaku mana yang paling adaptif. Manusia bertindak dengan tujuan tertentu. Dalam pengertian tertentu, manusia belajar melalui pengalaman mengenai apa yang diharapkan untuk terjadi, dan demikian mereka bisa menjadi semakin baik dalam memperkirakan perilaku apa yang akan memaksimalkan peluang untuk berhasil. Dengan demikian pengetahuan atau kesadaran manusia mengenai konsekuensi perilaku tertentu bisa membantu mengoptimalkan efektivitas suatu program pembelajaran.

Selanjutnya, penguat dalam teori pembelajaran sosial dipahami sebagai hal yang memiliki kualitas motivasi. Maksudnya, manusia belajar melakukan antisipasi terhadap penguat yang akan muncul dalam situasi tertentu, dan perilaku antisipasi awal ini menjadi langkah awal dalam banyak tahapan perkembangan. Orang tidak memiliki kemampuan untuk melihat masa depan, tetapi mereka bisa mengantisipasi konsekuensi-konsekuensi apa yang akan muncul dari perilaku tertentu berdasarkan 
apa yang mereka pelajari dari pengalaman baik dan buruk yang telah dialami orang lain (dan yang terpenting, tanpa langsung menjalani sendiri pengalaman itu). ${ }^{3}$

Dengan demikian inti dari pembelajaran modeling adalah (1) Mencakup penambahan dan pencarian perilaku yang diamati, untuk kemudian melakukan generalisasi dari satu pengamatan ke pengamatan lain. (2) Modeling melibatkan proses-proses kognitif, jadi tidak hanya meniru. Tetapi menyesuaikan diri dengan tindakan orang lain dengan representasi informasi secara simbolis dan menyimpannya untuk digunakan di masa depan. (3) Karakteristik modeling sangat penting. Manusia lebih menyukai model yang statusnya lebih tinggi daripada sebaliknya, pribadi yang berkompeten daripada yang tidak kompeten dan pribadi yang kuat daripada yang lemah. Artinya konsekuensi dari perilaku yang dimodelkan dapat memberikan efek bagi pengamatnya.(4) Manusia bertindak berdasarkan kesadaran tertentu mengenai apa yang bisa ditiru dan apa yang tidak bisa. Tentunya manusia mengantisipasi hasil tertentu dari modeling yang secara potensial bermanfaat. ${ }^{4}$

Kajian asumsi penting lain yang perlu dibahas dalam teori belajar sosial Albert Bandura adalah determinisme timbal balik (reciprocal determinism). Menurut pandangan ini, pada tingkatan yang paling sederhana masukan indrawi (sensory input) tidak serta merta menghasilkan perilaku yang terlepas dari pengaruh sumbangan manusia secara sadar. Sistem ini menyatakan bahwa tindakan manusia adalah hasil dari interaksi tiga variabel, lingkungan, perilaku dan kepribadian.

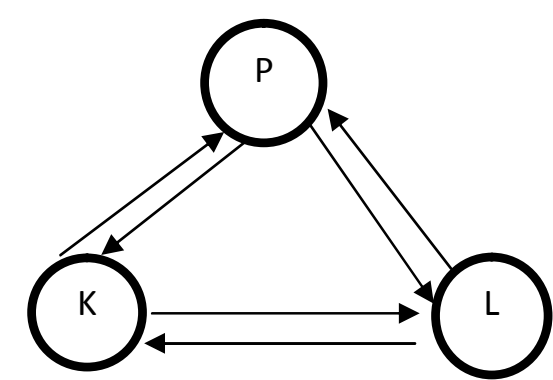

Konsep Bandura tentang reciprocal determinism.

Fungsi psikologis manusia adalah produk dari interkasi P (perilaku), K (kepribadian) dan L (lingkungan).

Inti reciprocal determinism adalah manusia memproses informasi dari model dan mengembangkan serangkaian gambaran simbolis perilaku melalui pembelajaran yang bersifat coba-coba kemudian disesuaikan dengan manusia. Ketiga faktor yang resiprok ini tidak perlu sama kuat atau memiliki kontribusi setara. Potensi relatif 
ketiganya beragam, tergantung pribadi dan situasinya. Pada waktu tertentu perilaku mungkin lebih kuat pengaruhnya. Namun, di lain waktu lingkungan mungkin memberikan pengaruh paling besar. Meskipun perilaku dan lingkungan terkadang bisa menjadi bisa menjadi kontributor terkuat suatu kinerja namun, kognisilah (kepribadian) kontributor yang paling kuat. Kognisi mempengaruhi perilaku, perilaku mempengaruhi kognisi. Lingkungan mempengaruhi perilaku, perilaku mempengaruhi lingkungan. Kognisi mempengaruhi lingkungan. Lingkungan mempengaruhi kognisi.

Pola reciprocal determinism ini menggunakan umpan balik, sampai akhirnya menemukan perilaku yang tepat sesuai dengan apa yang dikehendaki. Dengan demikian pembelajaran bukanlah merupakan proses sederhana di mana individu menerima suatu model dan kemudian meniru perilakunya, tetapi merupakan langkah yang jauh lebih kompleks di mana individu mendekati perilaku model melalui internalisasi atas gambaran yang ditampilkan oleh si model, kemudian diikuti dengan upaya menyesuaikan gambaran itu.

Bandura akhirnya memperluas konsep ini dengan nilai diri (self-value) dan keyakinan diri (self-efficacy). Self-efficacy adalah faktor person (kognitif) yang memainkan peran penting dalam teori pembelajaran Bandura. Self-efficacy yakni keyakinan bahwa seseorang biasa menguasai situasi dan menghasilkan perilaku yang positif. Keyakinan pada kemampuan diri sendiri untuk mengorganisir dan menggerakkan sumber-sumber tindakan yang dibutuhkan untuk mengelola situasisituasi yang akan datang.

Individu mengamati model bila ia percaya bahwa dirinya mampu mempelajari atau melakukan perilaku yang dimodelkan. Pengamatan terhadap model yang mirip mempengaruhi Self-efficacy (Kalau mereka bisa, saya juga bisa). Tinggi-rendahnya Self-efficacy berkombinasi dengan lingkungan yang responsif dan tidak responsif untuk menghasilkan empat variabel yang paling bisa diprediksi berikut ini:

(1) Bila Self-efficacy tinggi dan lingkungan responsif, hasil yang paling bisa diperkirakan ialah kesuksesan. (2) Bila Self-efficacy rendah dan lingkungan responsif, manusia dapat menjadi depresi saat mereka mengamati orang lain berhasil menyelesaikan tugas-tugas yang menurut mereka sulit. (3) Bila Selfefficacy tinggi bertemu dengan situasi lingkungan yang tidak responsif, manusia akan berusaha keras mengubah lingkungannya. Mereka mungkin akan menggunakan protes, aktivisme sosial, bahkan kekerasan untuk mendorong 
perubahan. Namun, jika semua upaya gagal, Bandura berhipotesis bahwa manusia mungkin akan menyerah, mencari laternatif lain, atau mencari lingkungan lain yang lebih responsif. Akhirnya, (4) Bila Self-efficacy rendah berkombinasi dengan lingkungan yang tidak responsif, manusia akan merasakan apati, mudah menyerah dan merasa tidak berdaya (Bandura, 1997; 115-116).

Self-efficacy dalam modeling akan mengacu pada tindakan-tindakan manusia, yang antara lain: (1) Manusia akan menerus merubah rencana ketika sadar konsekuensi dari setiap tindakan. (2) Manusia memiliki kemampuan memprediksi. Mengantisipasi hasil tindakan dan memilih perilaku mana yang dapat menghasilkan keluaran yang diinginkan serta menghindari yang tidak diinginkan. (3) Manusia sanggup memberikan reaksi diri dalam proses motivasi dan pengaturan terhadap setiap tindakan. Akhirnya (4) Manusia dapat melakukan refleksi diri. Menguji dirinya sendiri. Mengevaluasi sendiri motivasi, nilai, makna, dan tujuan hidupnya, bahkan sanggup memikirkan ketepatan pemikirannya sendiri. Self-efficacy melakukan tindakan-tindakan yang akan menghasilkan efek yang diinginkan. Prosesprosesyang mengatur pembelajaran dengan modeling, yaitu: ${ }^{5}$

1. Perhatian

Apakah faktor-faktor yang mengatur perhatian ini? Pertama, mengamati model yang padanya kita sering mengasosiasikan diri. Kedua, model-model yang aktraktif lebih banyak diamati. Individu harus mampu memberi perhatian pada model, kejadian dan unsur-unsurnya. Jika individu tidak bisa memberikan perhatian yang tepat pada suatu model, maka tidak mungkin terjadi peniruan. Faktor-faktor penguatan, kapasitas indrawi dan kompleksitas kejadian yang menjadi model merupakan faktor penting dalam proses perhatian ini.

2. Representasi

Agar pengamatan dapat membawa respons yang baru, maka pola-pola tersebut harus direpresentasikan secara simbolis di dalam memori. Proses menyimpan ciri-ciri terpenting dari suatu kejadian sehingga bisa dipanggil kembali dan digunakan ketika diperlukan. Ciri-ciri yang tersimpan dapat dalam bentuk pengkodean yang membantu kita mengujicobakan perilaku secara simbolis.

3. Produksi perilaku 
Setelah memberi perhatian kepada sebuah model dan mempertahankan apa yang sudah diamati, kita akan menghasilkan perilaku. Individu mampu secara fisik melaksanakan perilaku tersebut. Beberapa pertanyaan tentang perilaku yang dijadikan model,(1) Bagaimana saya melakukan hal tersebut. (2) Sudah benarkah tindakan saya ini?

4. Motivasi dan Reinforcement

Pembelajaran dengan mengamati paling efektif ketika subjek yang belajar termotivasikan untuk melakukan perilaku yang dimodelkan. Meskipun pengamatan terhadap orang lain dapat mengajarkan kita bagaimana melakukan sesuatu, tapi mungkin kita tidak memiliki keinginan untuk melakukan tindakan yang dibutuhkan. Reinforcement dapat memainkan beberapa peran dalam modeling. Bila mengantisipasi bahwa kita akan diperkuat untuk meniru tindakantindakan seorang model, kita mungkin akan lebih termotivasi untuk memperhatikan, mengingat dan mereproduksi perilaku itu. Bandura mengidentifikasi tiga bentuk reinforcement yang dapat mendorong modeling. (1) Pengamat mungkin mereproduksi perilaku model dan menerima reinforcement langsung. (2) Akan tetapi reinforcement tidak langsung bisa berupa vicarious reinforcement. Pengamat mungkin hanya melihat perilaku orang lain diperkuat dan produksi perilakunya meningkat. Dan bentuk (3) Self-reinforcement atau mengontrol reinforcement sendiri. Bentuk reinforcement ini penting bagi guru maupun siswa. ${ }^{6}$

Untuk menerapkan proses modeling kebanyakan pengamatan dimotivasi oleh harapan bahwa modeling yang tepat terhadap orang yang ditiru akan menghasilkan penguatan, juga penting diperhatikan bahwa orang juga belajar dengan melihat orang lain dikuatkan atau dihukum karena terlibat dalam perilaku tertentu.

Ada lima kemungkinan hasil dari modeling, yaitu: ${ }^{7}$

1. Mengarahkan perhatian. Dengan modeling orang lain, kita bukan hanya belajar tentang berbagai tindakan, tetapi juga melihat berbagai objek terlibat dalam tindakan-tindakan tersebut.

2. Menyempurnakan perilaku yang sudah dipelajari. Modeling menunjukkan perilaku mana yang sudah kita pelajari digunakan.

3. Memperkuat atau memperlemah hambatan. Modeling perilaku dapat diperkuat atau diperlemah tergantung konsekuensi yang dialami. 
4. Mengajarkan perilaku baru. Jika dalam modeling berperilaku cara baru (melakukan hal-hal baru), maka terjadi efek pemodelan.

5. Membangkitkan Emosi. Melalui modeling, orang dapat mengembangkan reaksi emosional terhadap situasi yang pernah dialami secara pribadi. ${ }^{8}$

Teori pembelajaran sosial Albert Bandura adalah pembelajaran dengan mengamati dan bertindak. Inti mengamati adalah pemodelan, yang mencakup pengamatan terhadap aktivitas-aktivitas yang benar, mengkodekan secara tepat kejadian-kejadian ini untuk dipresentasikan di dalam memori, melakukan performa aktual perilaku, dan menjadi cukup termotivasi. Pembelajaran dengan bertindak mengizinkan seseorang untuk mencapai pola-pola baru perilaku kompleks lewat pengalaman langsung dengan memikirkan dan mengevaluasi konsekuensikonsekuensi perilaku tersebut.

\section{PENERAPAN TEORI BELAJAR SOSIAL ALBERT BANDURA DALAM PROSES BELAJAR MENGAJAR DI SEKOLAH}

Teori belajar sosial Albert Bandura memaknai bahwa peserta didik memiliki sifat:

1. Intensionalitas

Peserta didik adalah perencana yang bukan hanya sekedar ingin memprediksi masa depan, tetapi intens membangun komitmen proaktif dalam mewujudkan setiap rencana.

2. Mem-prediksi

Peserta didik memiliki kemampuan mengantisipasi hasil tindakan, dan memilih perilaku mana yang dapat memberi keberhasilan dan perilaku yang mana untuk menghindari kegagalan.

3. Reaksi-diri

Peserta didik lebih daripada sekedar berencana dan merenungkan perilaku ke depan karena manusia juga sanggup memberikan reaksi-diri dalam proses motivasi dan meregulasi diri terhadap setiap tindakan yang dilakukan.

4. Refleksi diri

Peserta didik adalah mahkluk yang dilengkapi dengan kemampuan merefleksidiri. Kemampuan manusia merefleksi-diri, membentuk kepercayaan-diri dari 
manusia, bahwa manusia sanggup melakukan tindakan-tindakan yang akan menghasilkan efek yang diinginkan.

Bandura menjelaskan bagaimana kepribadian seseorang berkembang melalui proses pengamatan, di mana orang belajar melalui observasi atau pengamatan terhadap perilaku orang lain terutama orang yang dianggap mempunyai nilai lebih dari orang lainnya. Istilah yang terkenal dalam teori belajar sosial adalah modeling (peniruan).Menurut Bandura, kebanyakan belajar terjadi tanpa reinforcement yang nyata. Dalam penelitiannya, ternyata orang dapat mempelajari respon baru dengan melihat respon orang lain, bahkan belajar tetap terjadi tanpa ikut melakukan hal yang dipelajari itu, dan model yang diamatinya juga tidak mendapat renforsemen dari tingkahlakunya. Belajar melalui observasi jauh lebih efisien dibanding belajar melalui pengalaman langsung. Melalui observasi orang dapat memperoleh respon yang tidak terhingga banyaknya, yang mungkin diikuti dengan hubungan dan penguatan.

Tingkah laku manusia dalam bentuk interaksi timbal-balik yang terus menerus antara determinan kognitif, behavioral dan lingkungan. Manusia menentukan/mempengaruhi tingkahlakunya dengan mengontrol lingkungan, tetapi manusia juga dikontrol oleh kekuatan lingkungan itu. Saling-determinis sebagai prinsip dasar untuk menganalisis fenomena psiko-sosial di berbagai tingkat kompleksitas, dari perkembangan intrapersonal sampai tingkah laku interpersonal serta fungsi interaktif dari organisasi dan sistem sosial. Manusia dapat belajar melakukan sesuatu hanya dengan mengamati dan kemudian mengulang apa yang dilihatnya. Belajar melalui observasi tanpa ada reinforcement yang terlibat, berarti tingkah laku ditentukanoleh antisipasi konsekuensi.

Prinsip-prinsip teori belajar sosial Albert Bandura dalam proses belajar mengajar cenderung berorientasi pada:

1. Kepribadian seseorang berkembang melalui proses pengamatan, dimana orang belajar melalui pengamatan. Seseorang belajar melalui proses observasi atau pengamatan terhadap orang yang dianggap memiliki nilai lebih dibanding dirinya. Isi teori belajar sosial ini, cenderung mendorong hasrat untuk terus belajar. Setiap individu sekurang-kurangnya tetap mempertahankan akal sehat dan kemampuan pertimbangannya yang asli untuk menyikapi berbagai kondisi hidup aktual.Kemudian bergerak menggunakan bakat istimewa yaitu 
kesanggupan untuk belajar dari semua pengalaman yang telah dimiliki dan diperoleh selanjutnya.

2. Belajar melalui proses pengamatan (modeling)terjadi proses pengamatan terhadap segala yang dapat ditimba sebagai pengalaman sekarang dan merasakannya. Bahwa manusia selalu hidup pada saat di mana manusia itu hidup dan bukan pada suatu waktu lainnya. Hanya dengan setiap saat menyaring, seluruh makna dari setiap pengamatan yang dimatai sekarangini, maka manusia dipersiapkan untuk melakukan hal yang sama di masa yang akan datang. Ini satu-satunya persiapan yang akan membawa hasil.

3. Determenisme resipokal dalam teori belajar sosial Bandura, sebagai pendekatan yang menjelaskan tingkah laku manusia dalam bentuk hubungan interaksi timbal balik yang terus menerus, merupakan penerapan makna belajar mengajar dalam fungsi dan daya pedagogis. Bahwa setiap proses belajar mengajar yang bermakna memberi pengaruh timbal balik antara pengalaman kontinuitas dengan interkasi, sebagai pengalaman yang bersifat mendidik.

4. Tanpa reinforcement. Menurut Bandura reinforcement penting dalam menentukan apakah suatu tingkah laku akan terus terjadi atau tidak, tapi itu bukan merupakan satu-satunya pembentuk tingkah laku seorang individu.

5. Teori belajar sosial berusaha menjelaskan tingkah laku manusia dari segi interaksi feedback yang berkesinambungan antara faktor kognitif, tingkah laku, dan faktor lingkungan. Disinilah terletak kesempatan bagi manusia untuk mempengaruhi nasibnya maupun batas-batas kemampuannya untuk memimpin diri sendiri (self direction).

6. Teori belajar sosial Bandura dapat menerapkan prinsip pertumbuhan, kontinuitas dan rekonstruksi selama berlangsungnya proses belajar mengajar karena terjadi upaya penyesuaian diri. Namun penyesuaian diri itu bukanlah suatu hal yang pasif tetapi aktif, sebab organisme bertindak terhadap lingkungan tersebut dengan memberikan perubahan terhadapnya sesuai dengan usahanya dalam mempertahankan kehidupan dan menghadapi lingkungannya.

7. Mengkaji empat tahap belajar dari proses pengamatan atau modeling yang terjadi dalam observational learning yaitu: (1). Atensi, dalam seseorang harus memberikan perhatian terhadap model dengan cermat. (2). Retensi, mengingat kembali perilaku yang ditampilkan oleh model yang diamati maka seseorang 
perlu memiliki ingatan yang bagus terhadap perilaku model. (3). Reproduksi, memberikan perhatian untuk mengamati dengan cermat dan mengingat kembali perilaku yang telah ditampilkan oleh modelnya setelah itu adalah mencoba menirukan atau mempraktekkan perilaku yang dilakukan oleh modeldan (4). Motivasional, memiliki motivasi untuk belajar. Bahwa belajar yang berdasarkan bakat alami merupakan suatu proses dari upaya mengatasi kecenderungan alami dan menggantikannya degan berbagai kebiasaan yang diperoleh lewat dukungan eksternal. Gerak pemikiran manusia dibangkitkan dengan suatu keadaan yang menimbulkan permasalahan di dunia sekitar kita dan gerak itu berakhir dalam berbagai perubahan. Belajar dengan melibatkan dunia sosial mengandung di dalamnya integrasi antara subjek dan objek, juga pelaku dan sasarannya.

8. Konsep dasar teori efikasi diri adalah adanya keyakinan bahwa setiap individu mempunyai kemampuan mengontrol pikiran, perasaan dan perilakunya. Dengan demikian efikasi diri merupakan masalah persepsi subyektif. Artinya efikasi diri tidak selalu menggambarkan kemampuan yang sebenarnya, tetapi terkait dengan keyakinan yang dimiliki individu. Secara kodrati struktur psikologis manusia atau kodrat manusia mengandung kemampuan-kemampuan tertentu. Manusia yang sukses dalam hal ini adalah yang mampu memecahkan masalah-masalah dan menambahkan rincian-rincian dari proses-proses pemecahan masalah yang berbeda-beda ke dalam gudang pengalaman untuk digunakan menghadapi masalah-masalah yang mungkin saja mirip di masa akan datang.

Selanjutnya, proses belajar mengajarmelalui pengamatan terhadap orang lain atau vicarious conditioning sebagai adalah bentuk belajar secara kontinuitas dan berinteraksi. Proses vicarious conditioning atau modeling menjelaskan perilaku manusia dalam konteks interaksi timbal balik yang berkesinambungan antara kognitif, perilaku dan pengaruh lingkungan. Kontinuitas dan interaksi merupakan proses timbalbalik dan saling mempengaruhi antara makhluk hidup dan lingkungannya dalam rangka menunju ke kehidupan yang lebih baik. Vicarious conditioning atau modeling adalahpengalaman kontinuitas dan interkasi dengan lingkungan yang merangsang organisme melalui efikasi diri untuk memodifikasi lingkungan dalam hubungan timbal balik.

Faktor-faktor yang berproses dalam belajar observasi antara lain, 1)Perhatian(atensi), mencakup peristiwa meniru (adanya kejelasan, keterlibatan 
perasaan, tingkat kerumitan, kelaziman, nilai fungsi) dan karakteristik pengamat (kemampuan indra, minat, peresepsi, penguatan sebelumnya);2)Penyimpanan atau proses mengingat, mencakup kode pengkodean simbolik, pengorganisasian pikiran, pengulangan symbol, pengulangan motorik); 3)Reproduksi motorik, mencakup kemampuan fisik,kemampuan meniru, keakuratan umpan balik, dan 4) Motivasi, mencakup dorongan dari luar dan penghargaan terhadap diri sendiri. ${ }^{9}$

Beberapa cara yang dapat digunakan untuk menerapkan teori belajar sosial Albert Bandura dalam proses belajar mengajar adalah :

1) Mengaitkan pelajaran dengan pengalaman atau kehidupan siswa

2) Menggunakan alat pemusat perhatian seperti peta konsep, gambar, bagan, dan media-media pembelajaran visual lainnya.

3) Menghubungkan pesan pembelajaran yang sedang dipelajari dengan topik-topik yang sudah dipelajari.

4) Menggunakan musik.

5) Menciptakan suasana riang.

6) Teknik penyajian materi bervariasi.

7) Mengurangi bahan/materi yang tidak relevan.

Belajar memberikan ruang bagi terjadi proses mental, emosional dan fisik. Contoh aktifitas mental misalnya mengidentifikasi, membandingkan, menganalisis, dan sebagainya. Sedangkan yang termasuk aktifitas emosional misalnya semangat, sikap, positif terhadap belajar, motivasi, keriangan, dan lain-lain. Contoh aktifitas fisik misalnya melakukan gerak badan seperti kaki, tangan untuk melakukan ketrampilan tertentu.

Cara-cara yang dapat digunakan antara lain:

1) Memberikan pertanyaan-pertanyaan ketika proses pembelajaran berlangsung.

2) Mengerjakkan latihan pada setiap akhir suatu bahasan.

3) Membuat percobaan dan memikirkan atas hipotesis yang diajukan.

4) Membentuk kelompok belajar

5) Menerapkan pembelajaran kontekstual, kooperatif, dan kolaboratif.

Dalam merancang sebuah media pembelajaran, aspek yang paling penting untuk diperhatikanoleh seorang guru adalah karakteristik dan modalitas gaya belajar individu peserta didik. Media yang dirancang harus memiliki daya tarik tersendiri 
guna merangsang proses belajar mengajar yang menyenangkan. Suasana belajar di kelas menjadi kelas konstruktif yang merefleksikan proses pengetahuan dan pemahaman akuisisi,sehingga benar-benar melekat pada konteks sosial dan emosional saat belajar.

\section{KESIMPULAN}

1. Penerapan belajar sosial Albert Bandura dalam proses belajar mengajar memberi ruang bagi suatu proses belajar yang bergerak terus-menerus. Gerak yang terusmenerus terjadi mendorong munculnyamasalah sehingga memacu intelektual untuk memformulasikan usulan-usulan baru untuk bertindak. Konteks pembelajaran Pertama, mementingkan pengaruh lingkungan, mementingkan bagian-bagian, mementingkan peranan reaksi,mengutamakan mekanisme terbentuknya hasil belajar melalui prosedur stimulus respon. Kedua, mementingkan peranan kemampuan yang sudah terbentuk sebelumnya, mementingkan pembentukan kebiasaan melalui latihan dan pengulangan, hasil belajar yang dicapai adalah munculnya perilaku yang diinginkan.

2. Proses belajar mengajar di sekolah adalah kereaktifan diri yang menghubungkan pikiran dan tindakan. Faktor kecakapan, keyakinan, dan nilai memproses penekanan pada penciptaan pemahaman yang menuntut aktivitas yang kreatif dan produktif dalam konteks yang nyata. Kepribadian peserta didik berkembang melalui proses pengamatan, di mana peserta didik belajar melalui observasi atau pengamatan terhadap perilaku orang lain terutama pemimpin atau orang yang dianggap mempunyai nilai lebih dari orang lainnya.

3. Pembelajaran dalam bentuk Vicarious conditioningberlangsung sebagai suatu proses yang bergerak terus menerus dari suatu tahap ke tahapan rekonstruksi sebagaimana problem baru mendorong inteligensi untuk memformulasikan usulan-usulan baru untuk bertindak. Dengan prinsip, pengembangan pengalaman akan datang melalui interaksi berbagai aktivitas (means) .

\section{Endnotes:}

1 Jess Feist, Gregory J. Feist. Theories of Pesonality. Edisi keenam. (New York: McGraw Hill Companies, Inc, 2009). hlm.409.

${ }^{2}$ Neil J. Salkind,.An Introduction to theories of human development. (London: Sage Publications, 2004). hlm.211-213. 
${ }^{3}$ Ibid, 216

${ }^{4}$ Ibid, 217

${ }^{5}$ Ibid, 220

${ }^{6}$ Anita Woolfolk, Educational Psychology Active Learning Edition. (Boston: Allyn and Bacon, 2009). hlm. 342.

${ }^{7}$ Albert Bandura, Social Foudation of Thought and Action. (Englewood Cliffs, NJ: Prentice-Hall, 1986). hlm. 87

${ }^{8}$ Albert Bandura.Social Learning Theory. (Englewood Cliffs, NJ: Prentice-Hall, 1997). hlm. 24

${ }^{9}$ Ahmadi Abu.Psikologi Belajar. (Jakarta: Rineka Cipta, 2004), hlm. 34

\section{DAFTAR PUSTAKA}

Abu Ahmadi. 2004. Psikologi Belajar. Jakarta: Rineka Cipta.

Bandura, A. 1986. Social Foudation of Thought and Action. Englewood Cliffs, NJ: Prentice-Hall.

Bandura, A. 1982. Self-efficacy Mechanisme in Human Agency. American Pscyhologist, 37.

Bandura, A. 1977. Social Learning Theory. Englewood Cliffs, NJ: Prentice-Hall.

Dewey John. 2011. Democracy and Education. USA: The Pennsylvania.

Dewey John. 1963. Experience and Education, New York: Collier Macillan Publishers.

Feist J. Gregory, Jess Feist, 2008. Theories of Personality. Edisi keenam. New York: McGraw Hill Companies, Inc.

Salkind J. Neil. 2004. An Introduction to Theories of Human Development. London: Sage Publications.

Woolfolk A. Nita. 2009. Educational Psykology Active Learning Edition. Boston: Allyn and Bacon. 